mended, since its woven texture will survive long enough to provide a matrix for replacement by the standard textbook.

\section{DISEASES OF CHILDREN IN THE SUB- TROPICS AND TROPICS}

Edited by H. C. Trowell, O.B.E., M.D., F.R.C.P., and D. B. JellifFE, M.D., M.R.C.P., D.C.H., D.T.M. \& H. Pp. xvi+919. London: Edward Arnold Ltd. I958. 105s.

At last an attempt has been made to write a general book on diseases of children for use by medical students and doctors who live in the tropics - the attempt has been successful and this book can be recommended wholeheartedly.

The 75 contributors are drawn from such widely scattered places that the doctors in no tropical area can possibly feel that the authors of the book are entirely unfamiliar with their special local problems.

In every chapter there is a welcome and practical attitude to the prevention of disease. This is brilliantly exemplified by the illustrations in the section on liver fluke infection: on one page is a picture of a child defaecating into the water from a boat while the father fishes, and on the opposite page a picture of a family having a meal of raw fish at home.

Will the examiners for the Diploma in Child Health take note of this book ? If they do, perhaps the tendency to turn the minds of our visitors from the tropics even further towards an undue concern with rare diseases will be lessened.

The book is worth every one of the hundred and five shillings, but at a third of the price it would have a greatly increased sale and thus might be even more profitable to the publishers. T.S.

\section{NEOMYCIN: ITS NATURE AND PRACTICAL APPLICATION}

Edited by Selman A. Waksman. Pp. $x+412$. London: Baillière, Tindall \& Cox Ltd. 1958. 4os.

While neomycin is not one of the major antibiotics its relative importance, as well as that of other minor antibiotics, has increased as the problem of dealing with resistant organisms has become more difficult. We require to know a good deal about those agents which may enable us to rest the more widely used preparations or to conserve them for the most serious conditions.

Neomycin was originally considered as a tuberculocidal drug, but its severe toxic effects on hearing and on the kidney excluded it from parenteral use. Reconsideration of its properties have allowed it to be used occasionally. Probably one of the important features of neomycin, both from the point of view of medicine and of experimental bacteriology, is that it is in the bactericidal group of agents compatible with penicillin and streptomycin.
This book, edited by the great authority on the drug, gives all the available information on its production, chemistry and actions. W.H.H.

\section{RADIOISOTOPE TECHNIQUES IN CLINICAL RESEARCH AND DIAGNOSIS}

By N. Veall, B.Sc., F.Inst.P., and H. Vetter, M.D. Pp. xii +4I7. London: Butterworth \& Co. Ltd. I 958 . 5os.

This book presents in a very practicable form the considerable experience of the authors in the field indicated in the title. The 21 chapters fall naturally into two parts, of which the first gives a general treatment of the subject and the second deals with particular techniques in detail, concluding with a short chapter on isotope therapy.

After an account of the general principles underlying the use of radioactive isotopes, the authors give a full discussion of the apparatus available and deal with the choice of equipment, its calibration and use with different isotopes. This discussion, together with the chapters on the estimation of radiation dosage to patients and workers, would be particularly useful to clinicians without specialized training in physics who are interested in setting up an isotopes laboratory. This part of the book also contains an account of general isotope procedures and techniques, illustrated with some specific examples.

The second part of the book includes several chapters on blood studies and chapters on electrolyte studies, thyroid tests, fat and protein studies and the localization and diagnosis of malignant tumours. Thyroid tests are less fully treated than is customary in textbooks on clinical radioisotopes, but this is no great disadvantage as the subject is well covered elsewhere. The authors' account of clinical matters could be readily understood by a physicist new to this work and it provides an adequate physiological background to enable him to apply his own specialized knowledge to the clinical field.

The plan of the book sometimes leads to the same subject being treated several times from different points of view and it is therefore rather more suitable for reading as a whole than for quick reference on specific points. A good bibliography at the end of each chapter will enable those with specialized interests to pursue them further.

\section{THE KIDNEY}

\section{An Outline of Normal and Abnormal Structure and Function}

By H. DE WARdeneR, M.B.E., M.D., F.R.C.P. Pp. viii +338 , illustrated. London: J. \& A. Churchill Ltd. 1958. $45 \mathrm{~s}$.

Knowledge about the kidney in health and disease has increased greatly during the past two decades. British investigators have made important contributions in this field and Dr. de Wardener 